\title{
Culture Conditions for an $\alpha$-Amylase Inhibitor-Producing Marine Actinomycete and Production of the Inhibitor "Amylostreptin"
}

\author{
Chiaki Imada ${ }^{* 1,2}$ and Usio Simidu ${ }^{* 1,3}$
}

(Received June 18, 1992)

\begin{abstract}
Streptomyces corchorusii subsp. rhodomarinus subsp. nov. which was isolated from marine sediment produced an extracellular $\alpha$-amylase inhibitor named "amylostreptin". The optimal medium of the strain for the production of amylostreptin was investigated by using shake flask and an improved basal medium. Soluble starch as a carbon source and Polypepton as a nitrogen source were excellent for amylostreptin production as well as the growth of the strain. The maximum production of amylostreptin $\left(62.6 \times 10^{3}\right.$ units $/ 0.1 \mathrm{~m} l$ of broth) was observed in a medium consisting of $1.0 \%$ soluble starch, $1.2 \%$ Polypepton, and $0.1 \%$ Bacto-yeast extract at pH 7.5 in $25 \%(\mathrm{v} / \mathrm{v})$ seawater. Under the optimal cultivation conditions mentioned above, the production of amylostreptin increased about 3 times compared to the initial level.

The crude amylostreptin was very stable up to $100^{\circ} \mathrm{C}$ for $30 \mathrm{~min}$ as well as in a wide range of pH stability from 1 to 13.
\end{abstract}

Recently, amylase inhibitors have received increasing attention because they are not only a useful tool for the study of the active site of amylases," but also potential drugs for carbohydrate-dependent diseases such as diabetes, obesity, and hyperlipaemia. ${ }^{2-4)}$

As reported previously, the authors examined a large number of marine bacteria and actinomycetes for amylase inhibitor-producing activity, and encountered an actinomycete strain from a sediment sample of a marine environment.s) We named this amylase inhibitor "amylostreptin". It was necessary to investigate the improvement in production of the inhibitor because of the potential applications of the inhibitor in industry, medicine, and biochemistry. Culture conditions such as the composition of medium, $\mathrm{pH}$, and various physiological factors affect the production of secondary metabolites like antibiotics $\left.{ }^{\natural}, 7\right)$ and enzyme inhibitors. ${ }^{8-10)}$

This paper describes the results of an investigation for establishing the optimal cultivation conditions as well as some properties of the inhibitor.

\section{Materials and Methods}

\section{Microorganism}

Streptomyces corchorusii subsp. rhodomarinus T-178 isolated from a marine sediment $(5 \mathrm{~m}$ depth) of Aburatsubo Inlet, Kanagawa, Japan was used throughout this experiment. ${ }^{5)}$ The strain was maintained on an inorganic salt-starch agar medium (ISP No. 4) ${ }^{11)}$ at $10^{\circ} \mathrm{C}$.

\section{Cultivation of Microorganism}

A liquid medium composed of $0.6 \%$ Polypepton (Daigo Eiyo Kagaku), 0.1\% Bacto-yeast extract (Difco), and 1.0\% soluble starch in full strength seawater, $\mathrm{pH} 7.0$, was used for the initial culture of the microorganism. A hundred milliliters of the medium was put into a $500 \mathrm{ml}$ Erlenmeyer flask and inoculated from a slant culture. Incubation was carried out on a rotary shaker (speed, $200 \mathrm{rpm}$; eccentricity, $7 \mathrm{~cm}$ ) at $20^{\circ} \mathrm{C}$ until the logarithmic growth phase. Then, $2 \mathrm{ml}$ of the preculture was inoculated in $100 \mathrm{ml}$ of the same medium and incubated for 2 days at $20^{\circ} \mathrm{C}$. The growth of the strain was assessed by the weight of mycelium from $5 \mathrm{ml}$ of the broth, and after drying at $60^{\circ} \mathrm{C}$ for $2 \mathrm{~h}$. The mycelium was

*1 Ocean Research Institute, The University of Tokyo, Nakano, Tokyo 164, Japan（今田千秋，清水 潮: 東京大学海洋研究所)。

*2 Present adress: Institute of Microbial Chemistry, Kamiosaki, Shinagawa, Tokyo 141, Japan（微生物化 学研究所)

*3 Present adress: Faculty of Applied Biological Science, Hiroshima University, Kagamiyama, HigashiHiroshima, Hiroshima 724, Japan（広島大学生物生氺学部）。 
removed by centrifugation $(10,000 \mathrm{rpm}, 10 \mathrm{~min})$ and the inhibitory activity in the supernatant was assayed.

\section{Assay System for Amylase Inhibitory Activity}

Inhibitory activity of amylostreptin was assayed by a modified blue value method. ${ }^{12}$ The enzyme used for the assay was $\alpha$-amylase from human saliva type IX-A (Sigma) and was dissolved in $50 \mathrm{~mm}$ Tris-HCl buffer (pH 7.0) at the concentration of $5 \mu \mathrm{g} / \mathrm{m} l$. The substrate used was $0.5 \%$ soluble starch (Merck) solution in the same buffer. A reaction mixture containing $0.1 \mathrm{~m} l$ of suitably diluted culture supernatant and $0.2 \mathrm{ml}$ of enzyme solution was preincubated at $30^{\circ} \mathrm{C}$ for $10 \mathrm{~min}$. Then, $0.2 \mathrm{~m} l$ of substrate was added to the preincubated mixture. The mixture was incubated for $12 \mathrm{~min}$ at $30^{\circ} \mathrm{C}$, then $0.2 \mathrm{~m} l$ of $1 \mathrm{M}$ acetic acid was added to terminate the enzyme reaction. Thereafter, $0.2 \mathrm{~m} l$ of iodine reagent $(0.2 \%$ iodine and $2 \%$ potassium iodide) was added. The volume was made up to $6 \mathrm{~m} l$ with deionized water, and the optical density of the resulting blue colour was measured at $690 \mathrm{~nm}$. One unit of inhibitory activity of amylostreptin was defined as the amount of inhibitor required to decrease the enzyme activity by $50 \%$ under the above conditions.

The Effect of Various Factors on the Growth of the Strain and Production of Amylostreptin

The seawater used in the present study was collected from the open ocean off the Japanese coast and was stored for several months in the dark. The salinity of the seawater thus obtained was $3.5 \%(\mathrm{w} / \mathrm{v})$. To investigate the effect of the concentration of seawater, it was diluted with deionized water. To study the effect of initial $\mathrm{pH}$, the medium was adjusted to various $\mathrm{pHs}$ (3.5-10.5) with $1 \mathrm{~N} \mathrm{NaOH}$ or $\mathrm{HCl}$. Various nitrogen and carbon compounds were added to the medium in order to find the most suitable nitrogen and carbon sources.

The time course of the growth of the strain, the fluctuation of $\mathrm{pH}$, and the production of the inhibitor during cultivation were examined. An aliquot of $5 \mathrm{~m} /$ of the broth was sampled every day.

\section{Thermostability of Amylostreptin}

The inhibitor was kept at $100^{\circ} \mathrm{C}$ for 10 to 60 $\min$ and the residual inhibitory activity was assayed.

\section{The $p H$ Stability of Amylostreptin}

The inhibitor solution was incubated at various pHs for $10 \mathrm{~min}$ at $30^{\circ} \mathrm{C}$. After incubation, the $\mathrm{pH}$ was adjusted to 7.0 , and the residual inhibitory activity was measured.

\section{Results}

The Effect of Preincubation Time on Degree of Inhibition

Inhibitory activity increased depending on increasing preincubation time and reached a maximum after $12 \mathrm{~min}$, indicating that the time required for enzyme-inhibitor (E-I) complex formation was $12 \mathrm{~min}$ (Fig. 1).

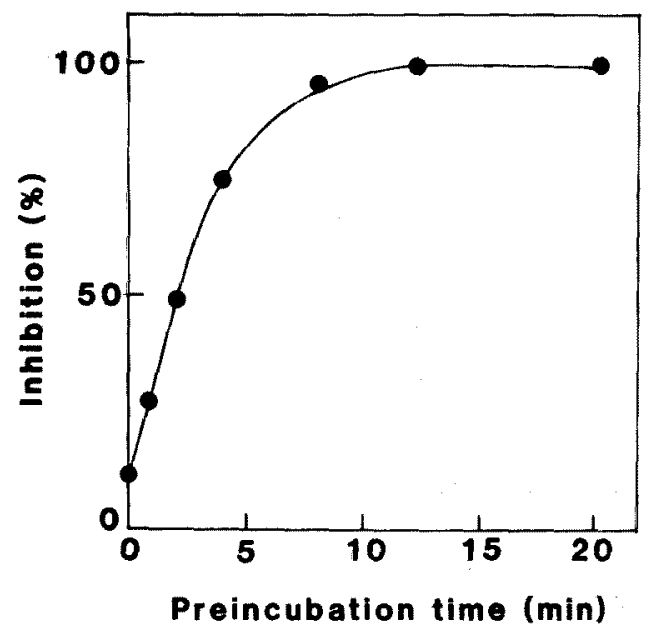

Fig. 1. The effect of preincubation time on the degree of intibiton.

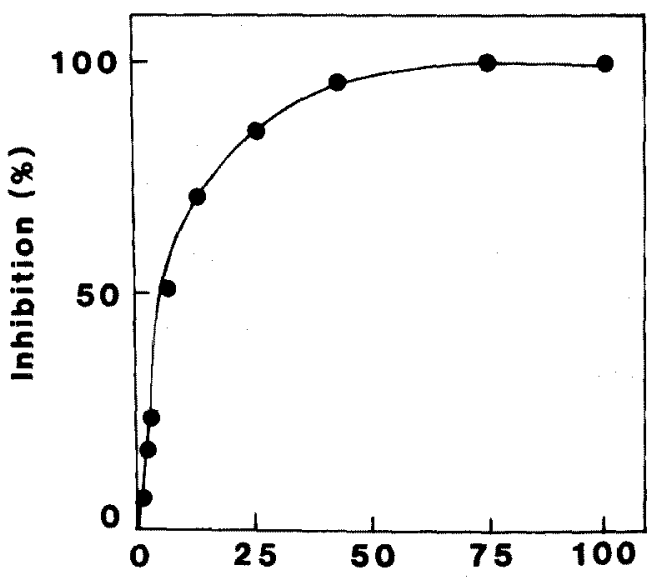

Arbitrary conc. of the inhibitor

Fig. 2. Percentage of inhibition versus arbitrary concentration of amylostreptin. 
Table 1. Effect of the concentration of seawater on the growth and inhibitor production

\begin{tabular}{cccc}
\hline $\begin{array}{c}\text { Seawater conc. } \\
(\%, \mathrm{v} / \mathrm{v})\end{array}$ & Final pH & $\begin{array}{c}\text { Growth }(\text { Mycelium } \\
\text { dry wt., } \mathrm{mg} / 0.1 \mathrm{~m} l)\end{array}$ & $\begin{array}{c}\text { Inhibitory activity } \\
\left(\times 10^{3} \text { units } / 0.1 \mathrm{ml}\right)\end{array}$ \\
\hline 0 & 7.9 & 0.21 & 28.6 \\
25 & 7.5 & 0.49 & 40.0 \\
50 & 7.4 & 0.56 & 32.4 \\
75 & 7.4 & 0.53 & 29.7 \\
100 & 7.3 & 0.49 & 22.0 \\
\hline
\end{tabular}

Basal medium: Polypepton $0.6 \%$, Bacto-yeast extract $0.1 \%$, soluble starch $1.0 \% \mathrm{pH} 7.0$.

Table 2. Effect of $\mathrm{pH}$ on the growth and inhibitor production

\begin{tabular}{rrrr}
\hline & $\mathrm{pH}$ & $\begin{array}{c}\text { Growth }(\text { Mycelium dry } \\
\text { wt., } \mathrm{mg} / 0.1 \mathrm{~m} l)\end{array}$ & $\begin{array}{c}\text { Inhibitory activity } \\
\left(\times 10^{3} \text { units } / 0.1 \mathrm{~m} l\right)\end{array}$ \\
\hline Initial & Final & 0.25 & 0.0 \\
4.5 & 3.7 & 0.58 & 26.9 \\
5.5 & 5.9 & 0.59 & 51.7 \\
6.5 & 7.6 & 0.51 & 55.2 \\
7.5 & 7.9 & 0.51 & 58.3 \\
8.5 & 8.1 & 0.43 & 21.0 \\
9.5 & 8.4 & 0.36 & 1.0 \\
10.5 & 8.3 & 0.17 & 0.0 \\
\hline
\end{tabular}

Basal medium: Polypepton $0.6 \%(w / v)$, Bacto-yeast extract $0.1 \%(w / v)$, soluble starch $1.0 \%(w / v)$, seawater $25 \%(v / v)$.

Percentage of Inhibition versus Arbitrary Concentration of Amylostreptin

The correlation between the amount of amylostreptin and inhibition against $\alpha$-amylase was not linear above a concentration which displayed $68 \%$ inhibition, as shown in Fig. 2. It was necessary to determine the inhibitory activity within the linear range (0-68\% inhibition).

The Effect of Various Factors on the Growth of the Strain and Production of Amylostreptin

Table 1 shows the effect of the concentration of seawater on the growth of the strain and the production of amylostreptin. Fifty percent $(\mathrm{v} / \mathrm{v})$ of seawater was the most suitable for growth of the strain, whereas $25 \%(v / v)$ of seawater was the best for the production of amylostreptin. The growth as well as the production of the inhibitor was less effective in the absence of seawater.

From the result shown in Table 2, an initial $\mathrm{pH}$ of 7.5 was found to be the most favorable for production. Consequently, the initial $\mathrm{pH}$ of the basal medium in $25 \%(\mathrm{v} / \mathrm{v})$ seawater was set at 7.5 for further investigations. When amylostreptin was produced, the final $\mathrm{pH}$ of the broth changed to about 8 .

Various mono-, di-, and polysaccharides, and sugar alcohols were tested as carbon sources in terms of production and growth of the strain. As shown in Table 3, soluble starch was the most effective and the optimal concentration for production was $1.0 \%(\mathrm{w} / \mathrm{v})$. Higher concentrations of soluble starch caused an adverse effect on the production. Several carbohydrates such as lactose, arabinose, sucrose, and maltose were less effective either for production or growth. From these results, soluble starch was added at a concentration of $1.0 \%(\mathrm{w} / \mathrm{v})$ to $25 \%(\mathrm{v} / \mathrm{v})$ seawater basal medium at $\mathrm{pH} 7.5$.

From the results shown in Table 4, it is apparent that inorganic nitrogen compounds such as $\mathrm{NH}_{4} \mathrm{NO}_{3}$ and $\mathrm{NH}_{4} \mathrm{Cl}$ were not effective for growth or inhibitor production. Complex organic nitrogen sources such as Bacto-gelatin, Bactocasamino acids, and Pharmamedia were also not effective for production or growth. Among the various nitrogen sources, Polypepton was found to be excellent for growth as well as production and the optimal concentration was 1.2 or $1.8 \%$ $(w / v)$. The final medium for the study of the time course of growth and the production of inhibitor was composed of $1.0 \%$ soluble starch, $1.2 \%$ Polypepton, and $0.1 \%$ Bacto-yeast extract in $25 \%(\mathrm{v} / \mathrm{v})$ seawater at $\mathrm{pH} 7.5$.

Figure 3 illustrates the time course of growth of the strain, the fluctuation of $\mathrm{pH}$, and the production of amylostreptin. After inoculation 
Table 3. Effect of carbon source on the growth and inhibitor production

\begin{tabular}{|c|c|c|c|c|}
\hline Carbon source & $\begin{array}{l}\text { Conc. } \\
(\%, w / v)\end{array}$ & Final $\mathrm{pH}$ & $\begin{array}{l}\text { Growth (Mycelium } \\
\text { dry wt., } \mathrm{mg} / 0.1 \mathrm{~m} l)\end{array}$ & $\begin{array}{l}\text { Inhibitory activity } \\
\left(\times 10^{3} \text { units } / 0.1 \mathrm{~m} l\right)\end{array}$ \\
\hline None & 0.0 & 8.4 & 0.28 & 1.9 \\
\hline Soluble starch & 0.5 & 7.6 & 0.38 & 28.6 \\
\hline Soluble starch & 1.0 & 8.0 & 0.43 & 58.3 \\
\hline Soluble starch & 2.0 & 7.0 & 0.78 & 30.2 \\
\hline Glucose & 1.0 & 6.6 & 0.53 & 2.3 \\
\hline Lactose & 1.0 & 8.4 & 0.27 & 2.0 \\
\hline Levulose & 1.0 & 7.8 & 0.44 & 2.6 \\
\hline Arabinose & 1.0 & 7.9 & 0.31 & 2.7 \\
\hline Galactose & 1.0 & 8.3 & 0.31 & 2.6 \\
\hline Xylose & 1.0 & 8.2 & 0.29 & 2.1 \\
\hline Sucrose & 1.0 & 8.4 & 0.28 & 2.2 \\
\hline Maltose & 1.0 & 8.4 & 0.26 & 1.4 \\
\hline Starch, wheat & 1.0 & 7.6 & 0.55 & 58.1 \\
\hline Starch, corn & 1.0 & 7.7 & 0.60 & 52.8 \\
\hline Starch, sweet potato & 1.0 & 7.6 & 0.51 & 50.6 \\
\hline Starch, potato & 1.0 & 7.6 & 0.32 & 28.6 \\
\hline Laminarin & 1.0 & 8.2 & 0.42 & 9.3 \\
\hline Glycerol & 1.0 & 5.6 & 0.53 & 10.3 \\
\hline Inuline & 1.0 & 8.3 & 0.36 & 2.5 \\
\hline Amylose & 1.0 & 8.0 & 1.21 & 6.9 \\
\hline Dextrin & 1.0 & 7.6 & 0.51 & 37.6 \\
\hline Mannitol & 1.0 & 7.9 & 0.55 & 12.1 \\
\hline Inositol & 1.0 & 8.2 & 0.30 & 8.8 \\
\hline Dulcitol & 1.0 & 8.3 & 0.35 & 2.6 \\
\hline
\end{tabular}

Basal medium: Polypepton $0.6 \%(\mathrm{w} / \mathrm{v})$, Bacto-yeast extract $0.1 \%(\mathrm{w} / \mathrm{v})$, seawater $25 \%(\mathrm{v} / \mathrm{v})$, pH 7.5 .

Table 4. Effect of nitrogen source on the growth and inhibitor production

\begin{tabular}{|c|c|c|c|c|}
\hline Nitrogen source & $\begin{array}{l}\text { Conc. } \\
(\%, w / v)\end{array}$ & Final pH & $\begin{array}{l}\text { Growth (Mycelium } \\
\text { dry wt., } \mathrm{mg} / 0.1 \mathrm{~m} l \text { ) }\end{array}$ & $\begin{array}{l}\text { Inhibitory activity } \\
\left(\times 10^{3} \text { units } / 0.1 \mathrm{~m} l\right)\end{array}$ \\
\hline None & 0.0 & 5.6 & 0.20 & 0.6 \\
\hline Polypepton & 0.3 & 6.3 & 0.49 & 44.1 \\
\hline Polypepton & 0.6 & 7.4 & 0.64 & 62.6 \\
\hline Polypepton & 1.2 & 8.1 & 0.95 & 65.8 \\
\hline Polypepton & 1.8 & 8.2 & 1.03 & 65.8 \\
\hline $\begin{array}{l}\text { Proteose peptone } \\
\text { No. } 3 \text { (Difco) }\end{array}$ & 0.6 & 8.3 & 0.32 & 4.5 \\
\hline Bacto-soytone & 0.6 & 7.6 & 0.36 & 32.1 \\
\hline Phytone (BBL) & 0.6 & 7.9 & 0.30 & 18.0 \\
\hline Bacto-casitone & 0.6 & 7.4 & 0.40 & 33.2 \\
\hline Bacto-tryptose & 0.6 & 5.4 & 0.65 & 19.1 \\
\hline Meat extract & 0.6 & 8.2 & 0.40 & 16.9 \\
\hline Bacto-gelatin & 0.6 & 7.9 & 0.22 & 8.4 \\
\hline Bacto-casamino acids & 0.6 & 8.3 & 0.37 & 0.5 \\
\hline Corn steep liquor & 0.6 & 5.9 & 0.15 & 5.3 \\
\hline Pharmamedia* & 0.6 & 5.3 & 0.29 & 1.5 \\
\hline Bacto-tryptone & 0.6 & 7.7 & 0.35 & 18.0 \\
\hline Trypticase peptone & 0.6 & 7.8 & 0.38 & 28.9 \\
\hline Casein & 0.6 & 6.0 & 0.47 & 12.5 \\
\hline $\mathrm{NaNO}_{3}$ & 0.6 & 6.1 & 0.13 & 0.2 \\
\hline $\mathrm{NH}_{4} \mathrm{Cl}$ & 0.6 & 4.7 & 0.12 & 0.3 \\
\hline $\mathrm{NH}_{4} \mathrm{NO}_{3}$ & 0.6 & 5.2 & 0.13 & 0.3 \\
\hline
\end{tabular}

* Traders Oil Mill Co., USA.

Basal medium: Bacto-yeast extract $0.1 \%(w / v)$, soluble starch $1.0 \%(w / v)$, seawater $25 \%(v / v)$, pH 7.5 . 


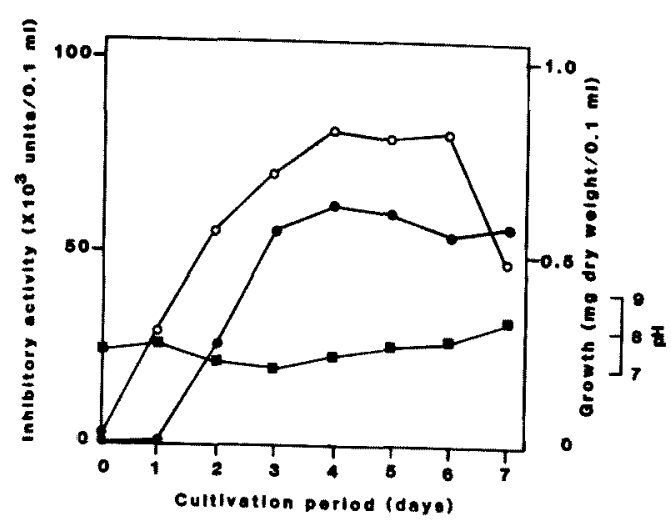

Fig. 3. Time course of the growth of the strain, fluctuation of $\mathrm{pH}$, and production of amy-

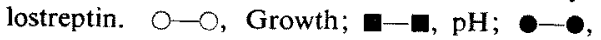
inhibitory activity.

of the strain, it grew steadily within 3 days, followed by a plateau afterwards. The production of amylosterptin was almost parallel to the growth. The maximum production was reached after 4 days and this level was maintained thereafter. However, there was not much fluctuation of $\mathrm{pH}$ in the broth and the $\mathrm{pH}$ remained between 7 and 8.5 throughout the experiment.

\section{Thermostability and $\mathrm{pH}$ Stability of Amylostreptin}

Amylostreptin was stable at $100^{\circ} \mathrm{C}$ with no loss of inhibitory activity up to $60 \mathrm{~min}$.

It was also quite stable in a $\mathrm{pH}$ range from 1 to 13 with a loss of no more than $20 \%$ of inhibitory activity.

\section{Discussion}

A number of amylase inhibitors were isolated and characterized from various plants. ${ }^{13)}$ However, inhibitors of microbial origin are limited in number. In terms of the production of useful substrates, microorganisms have advantages over plants: they grow fast, are easily and economically cultivated, and many experiments can be undertaken within a short period of time. In the present study, amylostreptin production increased more than three times under the modified condition compared to that under the initial culture conditions. In the case of protease inhibitor producing bacterium isolated from seawater, the production of the inhibitor also increased about three times by improving the culture conditions. ${ }^{14)}$ The production of amylostreptin was less effective in the presence of full-strength seawater, suggesting that this actinomycete was of a terrestrial origin. It may be transported to rivers through rain or irrigation water, finally brought to the marine environment and adapted to the environment.

Murao et $a{ }^{15}{ }^{15)}$ reported that an actinomycete strain isolated from soil required corn starch for the production of amylase inhibitors because chemical structures of these inhibitors were oligosaccharides. The same result was obtained in the present study, that is, the production of amylostreptin increased considerably in the presence of starch, suggesting that the chemical structure of amylostreptin was a saccharide. The crude amylostreptin was very thermostable and $\mathrm{pH}$ stable. It should be taken into consideration, however, that the amylostreptin used in the present study was in a crude form. Further studies of the purification of amylostreptin are underway.

\section{References}

1) M. D. O'Donell, O. Fitzgerald, and K. F. McGeeney: Differential serum amylase determination by use of an inhibitor, and design of a routine procedure. Clin. Chem., 23, 560-566 (1977).

2) W. Puls, U. Keup, H. P. Krause, G. Thomas, and F. Hoffmeister: Glucosidase inhibition. A new approach to the treatment of diabetes, obesity, and hyperlipoproteinaemia. Naturwissenschaften, 64, 536-537 (1977).

3) H. Frerichs, H. Daweke, F. Gries, D. Gruneklee, J. Hessing, K. Jahnke, U. Keup, H. Miss, H. Otto, W. Puls, D. Schmidt, and C. Zumfelde: A novel pancreatic amylase inhibitor (BAY d 7791). Experimental studies on rats and clinical observations in normal and obese diabetic and non-diabetic subjects. Diabetologia, 9, 68 (1973).

4) W. Puls and U. Keup: Influence of an $\alpha$-amylase inhibitor (BAY d 7791) on blood glucose, serum. Insulin and NEFA in starch loading tests in rats, $\operatorname{dog}$ and man. Diabetologia, 9, 97-101 (1973).

5) C. Imada and U. Simidu: Isolation and characterization of an $\alpha$-amylase inhibitor producing actinomycete from marine environment. Nippon Suisan Gakkaishi, 54, 1839-1845 (1988).

6) T. Okazaki, T. Kitahara, and Y. Okami: A new antibiotic SS-228 $Y$ produced by Chainia isolated from shallow sea mud. J. Antibiot, 28, 176-184 (1975).

7) T. Nara, M. Yamamoto, I. Kawamoto, K. Takayama, R. Okachi, S. Takasawa, T. Sato, and S. Sato: Fortimicins A and $B$, new aminoglycoside antibiotics. 1. Producing organism, fermentation and biological properties of fortimicins. J. Antibiot, 30, 533-540 (1977).

8) S. Murao and T. Nishino: Isolation and identification of aspartate aminotransferase inhibitor-producing microorganism. Agric. Biol. Chem., 47, 1531-1535 (1983).

9) S. Murao, N. Kasai, Y. Kimura, and K. Oda: Isolation of metallo-proteinase inhibitor (FMPI) producing microorganism. Agric, Biol. Chem., 46, 2697-2703 (1982).

10) S. Murao, N. Ouchi, A. Goto, and M. Arai: Isolation and identification of a pig pancreatic $\alpha$-amylase inhibitor (Paim) producing Streptomyces. Agric. Biol. Chem., 49, 107-110 (1985). 
11) E. B. Shirling and D, Gottlieb: Methods for characterization of Streptomyces species. Int. J. System. Bact., 16, $313-340$ (1966).

12) H. Fuwa: A new method for microdetermination of amylase activity by the use of amylose as the substrate. J. Biochem., 41, 583-603 (1954).

13) V. Buonocore, T. Petrucci, and V. Silano: Wheat protein inhibitors of $\alpha$-amylase. Phytochemistry, 16, 811-820 (1977).
14) C. Imada, N. Taga, and M. Maeda: Cultivation conditions for subtilisin inhibitor-producing bacterium and general properties of the inhibitor "Marinostatin". Nippon Suisan Gakkaishi, 51, 805-810 (1985).

15) S. Murao, K. Ohyama, and S. Ogura: Isolation of amylase inhibitor-producing microorganism. Agric. Biol, Chem., 41, 919-924 (1977). 